\title{
The Native American voice in United States water rights
}

\author{
Karen R. Marsh and Michael D. Smith
}

\section{ABSTRACT}

There is a sacred relationship between Native Americans and the environment. The importance of those sacred beliefs in water rights in the United States (US) is examined through a series of case studies. A thorough review of available literature displays a trend toward less dependence on the US for representation and a greater recognition of Native American traditions. The increased role of Native Americans in water rights quantification and resource development provides greater appreciation and understanding of their traditions and beliefs.

Key words: Native Americans, sacred beliefs, USA, water rights

Karen R. Marsh 228 Harbor Fog Trail, Holly Springs, NC, 27540, USA

Michael D. Smith (corresponding author) Water, Engineering and Development Centre, Loughborough University, The John Pickford Building, Loughborough, Leicestershire LE11 3TU, UK. E-mail: <M.D.Smith@lboro.ac.uk>

\section{INTRODUCTION}

Native Americans are a distinct population in the United States (US). They are recognized as sovereign peoples, with power to develop and enforce their own laws. In addition, they share a government-to-government relationship with the US. Further, Native Americans are the only population to receive specific water rights different from the rest of the general population. This grants them a unique opportunity for claims to significant quantities of water.

\section{Project aim}

Native Americans have developed environmentally sustainable traditions over generations. These traditions have taught them how to respect and value natural resources. However, these traditions may be inconsistent with the typical mainstream water management practices in the US. The aim of this project was, therefore, to assess whether decisions related to the water rights of Native Americans reflect their environmental beliefs.

\section{Research questions}

This research explored the influence of Native American traditions and beliefs on decisions related to water rights and allocation. The principal research question was, 'How do decisions about Native American water rights reflect the traditions and beliefs of the Native American population?'

In addition, several underlying questions were addressed.

- 'How are Native Americans represented within the court system?'

- 'What are the justifications for final decisions concerning the water rights of Native Americans?'

- 'Have these justifications changed over time?'

\section{Methodology}

Conducting research within the Native American community is difficult. Traditional beliefs and customs are considered sacred and proprietary (Harris \& Harper $\square$ 1997). In addition, historical disputes between tribes and settlers have led to Native Americans mistrusting outsiders. Formal surveys and questionnaires are typically not used when conducting research involving Native American tribes. Literature reviews that draw on respected and reliable publications are, therefore, valuable sources of information for this topic.

This research utilized the literature to investigate whether decisions made through the legal system concerning Native American water rights accurately reflected the beliefs of those 
populations. Three key decisions affecting water rights were chosen for examination as individual case studies: Winters v. United States (1908), McCarran Amendment (1952), and Arizona v. California (1963). In each case the final court decision and related literature evaluating that decision were reviewed. Finally, the current status of water rights cases in the US was examined, considering recent negotiations.

\section{Outline of article}

This article presents the information collected through literature reviews. Following a presentation of the beliefs of Native Americans, the various water rights law systems of the US are presented. Each case is then evaluated from a historical perspective to understand the basis for each decision. A discussion of the relevant beliefs of Native Americans in relation to each case is then provided. Finally, conclusions and recommendations for further study are identified.

\section{NATIVE AMERICAN POPULATIONS}

The US Census breaks down race into six categories: (i) White, (ii) Black or African American, (iii) American Indian or Alaska Native, (iv) Asian, (v) Native Hawaiian or other Pacific Islander, or (vi) some other race. The American Indian or Alaska Native race group is defined as 'a person having origins in any of the original peoples of North and South America (including Central America) and who maintains tribal affiliation or community attachment' (USCB 2014). For the purposes of this research, the term Native Americans is used to include American Indians and Alaska Natives.

According to the 2011 American Community Survey, the population of Native Americans was approximately 5.1 million, or $1.6 \%$ of the total population (US Census Bureau 2011). Individual tribes must apply to the Bureau of Indian Affairs (BIA) in order to be federally recognized and eligible for funding and services from the BIA. As of 2014, there were 566 federally recognized tribes in the US (BIA 2014). These tribes reside throughout the US, with the highest populations in the states of California, Oklahoma, Arizona, Texas, New Mexico, Washington, North Carolina, New York, Florida, Michigan, Alaska, Colorado, Oregon, and Minnesota (USCB 2011).

\section{BELIEFS}

The relationship between Native Americans and the natural environment can be traced back thousands of years. General themes are present in the relationship among all tribes. It is a relationship that is perceived as sacred. Governor Frank Tenorio of the San Felipe Pueblo describes this relationship, stating, the land 'is our body', the values of the tribal culture are 'our soul', and the water 'is the blood' (AIJ 1978). Chief Oren Lyons, of the Iroquois Confederacy in New York, further supports these statements by saying that 'everything has a spirit' (Lyons n.d.). This view of a connection with nature is prevalent throughout literature about Native American traditions. In their endorsement and adoption of the Indigenous Declaration on Water (IDW), the Indigenous Environmental Network stated, 'water, like life, is sacred' (IEN 2001).

This sacredness does not mean that Native Americans live, or believe they should live, in a manner that results in no changes to the environment. In fact, generations of tribes have shaped their surroundings to meet their needs, such as burning and targeted harvesting in the Sierra Nevada region (Anderson \& Moratto 1996). However, their transformations of the environment were specific to their needs and the environmental impacts were temporary as they lacked the type of technology to cause irreversible damage (Kline 2000).

One key aspect of the traditions of Native Americans reflects a sense of respect and sustainable management. This is perhaps what has made Native American beliefs into 'the standard' for environmental preservation (Kline 2000). There is a belief that man was not created to rule over creation, but to collaborate and share what is provided by the Earth 
(Cornell 1990). As part of the IDW, tribes agreed that their rights and responsibilities have been ignored. The shared belief is that the creator entrusts man with the responsibility to protect water (IEN 2001).

The sacredness of the Earth is a key influence over decisions made within Native American tribes. Literature is filled with the theme that Earth is the body and water is the lifeblood (IEN 2001). No information is known to exist to show how the US has incorporated this belief directly in decisions related to water rights, although the US has developed environmental legislation.

\section{US water laws}

There is no national system for the allocation of water within the US. Federal control of water resources is limited to navigable waters (Walston 2006). States were charged with regulating other water uses (CBO 2006). However, one exception to this authority applies to lands that are owned by the US, including national parks (Walston 2006) and Native American reservations (Getches 1997). Reserved rights originate from the case commonly known as 'Winters v. United States' (Winters 1908) and are discussed in the case study presented later in this article.

Native American reserved water rights do not fall under the jurisdiction of state laws, but a decision enacted in 1952, referred to as the McCarran Amendment, gave states the right to adjudicate and administer water rights (Canby 2004). It is, therefore, important to understand the systems implemented by the individual states because this amendment brought Native American water rights under state jurisdiction.

Each individual state has established its own water codes for determining water rights. These codes govern water resources to guarantee that the source is not overused. Two unique doctrines, 'riparian' and 'prior appropriation', were historically used as templates for state codes (Getches 1997). Different approaches may apply within some individual states, based on legal precedent or for historical reasons.

\section{Riparian system}

Riparian rights are based on land ownership. Fundamentally, a landowner is entitled to use any water that is located on or bordering his property for any purpose provided that this use does not interfere with other landowners downstream. This is referred to as a 'reasonable use' (Getches 1997). This doctrine was the original doctrine used in the US because most of the colonies were located in the east, where water sources were more abundant. As such, most of the eastern states still consider riparian rights applicable for water allocation.

While this system has worked since colonization, there are several issues for Native Americans. First, when tribes ceded lands to the US in treaties, they forfeited their property rights. The US is the owner of reservation lands (Babcock 2006). Tribes, therefore, have no property claim to water on or bordering their reservations. In addition, certain traditional lifestyles of tribes, such as fishing, are difficult to classify as 'reasonable uses' (Babcock 2006). Lastly, disputes among users require proof of injury. The lack of funds and representation of Native Americans in courts mean that disputes are not recognized, resulting in further injury to the tribes. However, Native American water rights should not be affected by these situations because of the reserved rights doctrine.

\section{Prior appropriation system}

The prior appropriation doctrine utilizes 'first in time, first in right' (Getches 1997). That is, the first person to put water to a beneficial use has the highest priority for rights. As users share the water, the most senior user has priority and retains his entire allotment, even during shortages.

This doctrine differs from the riparian doctrine because water use is not tied to the location of water sources. This distinction is critical for two reasons. First, movement of settlers to the west was driven by the abundance of mineral deposits in the land (Getches 1997). These deposits were not located adjacent to water sources, so water was diverted to the mines. 
Diversions also made agriculture possible. Second, the US held title to the land in the west. Settlers were not landowners, and thus not afforded rights to waters based on ownership.

Three key benefits to this system exist: stability, clarity, and permanence (Babcock 2006). Senior water users have priority to access their allocated quantities of water at all times. In most cases, Native Americans were granted senior rights to water by the establishment of priority dates from the signature of a treaty (Canby 2004). However, Native Americans have not claimed their full rights, resulting in negative impacts. For instance, existing users may lose their allotments when Native Americans claim their entitlement to waters. Thus, Native American water rights create an uncertainty for users in prior appropriation states.

\section{Other systems}

\section{Hybrid systems}

There are several problems associated with purely riparian or prior appropriation systems (Deason et al. 2001). Several states originally used the riparian doctrine, but scarcity of resources led to the adoption of key policies from the prior appropriation doctrine. Adopting a hybrid system suggests that a key distinction was recognized; the rights associated with the use of water are more important than those associated with ownership (Hu 2006).

There is no set standard followed by the 10 states using hybrid systems. California law, for example, has recognized claims to water under both riparian and prior appropriation systems (Getches 1997). In some cases, prior use of water affords the rights to the first user, consistent with prior appropriation. However, miners became landowners when the US conveyed plots of land to settlers. In these instances, California courts have upheld riparian rights to that water, only where no prior appropriations were in place (Getches 1997).

\section{Other systems}

Two states, Hawaii and Louisiana, have unique water rights systems that do not fit into any of the above-mentioned systems. Hawaii's system is based on land tenure, where chiefs were in control of units of land that generally followed watershed areas (Getches 1997). There are no recognized Native American tribes in Hawaii, but Native Hawaiians and Pacific Islanders are considered separately for census purposes (US DOC 2001).

Louisiana law is based on the Civil Codes of France and Spain (Getches 1997) and is similar to the riparian doctrine. Rights are based on reasonable use, with a consideration for water pollution (Getches 1997). Four federally recognized Native American tribes are located in Louisiana (US DOI 2002).

Finally, a few areas of Arizona, California, Colorado, New Mexico, and Texas recognize rights created by Spanish or Mexican governments. These rights allow municipalities the use of all water, within their land boundaries, that is necessary for their residents. These are referred to as pueblo rights (Getches 1997).

\section{CASE STUDIES}

\section{Winters v. US}

Montana was once the territory occupied by the Gros Ventre, Assiniboine, Blackfeet, Piegan, Blood, and River Crow tribes. Through a series of treaties beginning in 1851, the US established reservations for these tribes. Fort Belknap was established as the home of the Gros Ventre and Assinibione tribes.

Once on the reservation, some of the Native Americans chose to abandon the traditional nomadic hunter lifestyle in favor of a farming lifestyle. This transformation was encouraged by the treaties, which stated that materials were supplied to 'undertake the cultivation of the soil and engage in pastoral pursuits' (Kappler n.d.). It is unclear if this was actually the desire of the Native Americans. For example, the preamble to the 1887 treaty stated the cession of land was due to the lands being 'greatly in excess of their present or prospective wants' and 
the 'Indians are desirous of disposing of so much...to become self-supporting, as a pastoral and agricultural people, and to educate their children in the paths of civilization' (Kappler n.d.). This gives one perspective, but no evidence exists to interpret the actual desires of the tribes.

This lifestyle change required a change to the landscape. An irrigation ditch was constructed from the Milk River, which formed the northern border of the reservation. It was recognized that without irrigation the lands were not valuable. The 1896 treaty stated, 'the scarcity of water on this reservation renders the pursuits of agriculture difficult and uncertain' (Kappler n.d.). Raising livestock thus became the focus of the reservation.

By 1905, settlers occupied the area upstream of the reservation. In accordance with Montana laws, these settlers diverted water from the Milk River, through irrigation channels, and used it for agriculture. A drought occurred in 1905, leaving the irrigation ditch on the reservation dry. This was the catalyst that spurred Superintendent William R. Logan to ask the US for assistance to obtain enough water for the Native Americans to live and grow food.

Superintendent Logan was assigned to Fort Belknap and frequently reported back to the commissioner of Indian affairs. In a letter to Francis Leupp, Logan relays the water scarcity issues, specifically stating, 'our meadows are now rapidly parching up' (Wunder 1996). The use of words in this letter implies that Logan identified with the Native Americans living at Fort Belknap and was speaking on their behalf and as their agent.

The initial case for water rights at Fort Belknap was brought to the district court in Helena, Montana. Judge William $\mathrm{H}$. Hunt presided over the case. The main objective of the case was to 'protect the rights of the Indians' (Hudley 1982).

Prior appropriation was initially used by Attorney Carl Rasch to assert senior priority for Fort Belknap. Under this claim, the reservation was entitled to 11,000 miner's inches of water (Hudley 1982). (11,000 miner's inches of water is approximately equal to 6.2 cubic meters per second. The measurement of a miner's inch is a representation of the flow of water through a hole of a given size and pressure and is equal to $7 \times 10^{-4}$ cubic meters per second). Rasch also claimed riparian rights because the northern border of the reservation was the mid-point of the Milk River. Judge Hunt considered both arguments.

On 7 August 1905 Judge Hunt revealed a stunning decision. He concluded that while the treaties did not specifically mention water rights, there was an implied reservation of enough water for irrigation (Hudley 1982). This decision was based on both the purpose of the treaty and the climatic conditions of Montana. The result was the reservation of enough water for Fort Belknap, subject to change as needs changed.

Immediately following the decision, the case was taken to the 9th Circuit Court of Appeals. The main argument was that Judge Hunt had given the Native Americans a right they did not actually want. The settlers believed the Native Americans did not intend to practice agriculture. No evidence supports this claim, however. In February 1906, Judge Hunt's ruling was upheld. The court stated, 'The government and the Indians...knew the 'soil could not be cultivated' without the use of water to 'irrigate the same" (Hudley 1982).

The US Supreme Court heard a final appeal in 1907. In January 1908, the Supreme Court upheld the original decision stating, 'It was the policy of the government, it was the desire of the Indians, to change those habits and to become a pastoral and civilized people...the lands were arid, and, without irrigation, were practically valueless.' Further, Judge McKenna recognized that 'the lands were ceded... and some argument may be urged...that with their cession there was the cession of the waters... and civilized communities could not be established thereon.' Presented with this conflict, the courts upheld the commonly practiced rule that states, 'Ambiguities occurring will be resolved from the standpoint of the Indians' (Winters v. United States 1908). Thus, rights to water for Native Americans were established.

\section{McCarran Amendment}

The US is entitled to a potentially large quantity of water in the west because it owns about $60 \%$ of the lands within the various watersheds (Kleppinger 1977; Pacheco 1988). It is, 
therefore, vital that any federal claims to water rights are considered when states appropriate waters for other users. However, there are two court systems, federal and state, in water rights claims when river systems with federal rights are involved (Pacheco 1988). This dual system for stream adjudications prompted Congress to develop and enact the McCarran Amendment (1952).

The McCarran Amendment waives the sovereign immunity of the US, allowing the US to join lawsuits within state courts involving the adjudication of rivers (McCarran Amendment 1952). Specifically, the Amendment grants states the right to appropriate and administer water rights for all waters within their borders (Stein 1997). By waiving sovereign immunity, the former practice of piecemeal adjudications is minimized, thus achieving the goal of equitable and organized allocation (Pacheco 1988). This practice is more efficient and effective because all parties are included in adjudications. When codified, the McCarran Amendment displayed the recognition by Congress that any action regarding one water user affected the rights of all other users (Stein 1997). The waiver of immunity also forces the US to claim water rights for all uses, even in the future. The McCarran Amendment eliminates this uncertainty for the states for water claims by the US in the future, thus allowing for better resource development and management.

\section{Arizona v. California}

One of the major issues resulting from the Winters v. United States (1908) decision was the quantification of water rights reserved for Native Americans. In Winters v. United States (1908), the courts determined that the quantity reserved was equal to the quantity needed to meet the present and future needs of the tribe. However, a lot of ambiguity about that specific quantity remained. 'Arizona v. California' (Arizona 1963) was the first case that provided a specific basis for determining this quantity.

Water rights associated with the Colorado River have received a lot of attention within the court system in the western US. The river itself is one of the greatest rivers in the US, draining a catchment area of 242,000 square miles and running a course through seven states (Trelease 1963). There are numerous potential water users, making a determination of which lands should receive the water vital.

In the first interstate agreement for water allocations, the Colorado River Compact divided the river into Upper and Lower Basins (Trelease 1963). The division was placed at Lee Ferry, in northern Arizona. The states included in the Upper Basin are Colorado, New Mexico, Utah, and Wyoming. The Lower Basin consists of Arizona, California, and Nevada. In the Compact, half of the flow (7.5 million acre-feet per year) was awarded to each basin (Trelease 1963).

Arizona remained concerned over the allotments of water in the Lower Basin, particularly those granted to California. Arizona's concern was that favor was shown to the California cities of San Diego and Los Angeles because it was easier to divert water to them than to areas of central Arizona, such as Phoenix. Arizona brought a suit against California in the US Supreme Court in 1952. Nevada, New Mexico, and Utah later joined because of their claims to the Colorado River. The US then also joined on behalf of five Native American tribes (Goodman 2005).

The main question before the Supreme Court was how much water each state and tribe should receive from the Colorado River and its tributaries (Arizona 1963). The Court relied on the Boulder Canyon Project Act to answer this question. Congress developed the Act to deal with the numerous issues facing the region: scarcity of water, continued disputes among the states, and the need for a system of dams, reservoirs, and public works for the control, storage, and distribution of the waters of the Colorado River (Arizona 1963).

In 1963, the United States Supreme Court determined that the allocations established in the Boulder Canyon Project Act were sufficient. Each state in the Lower Basin was awarded the already established quantities of water and rights to the tributaries wholly within each state. In addition, when surplus water is available for the Lower Basin, the surplus amount is split 
equally between Arizona and California (BCPA 1928). The Act did not, however, quantify the Native American water allocation.

\section{Practicably irrigable acreage}

The first widely used method for quantification of Native American water rights was the 'Practicably Irrigable Acreage (PIA)' method. Arizona I (1963) established PIA. PIA refers to the amount of water necessary to irrigate all of the reservation lands that are arable (Burness et al. 1982; Williams 1997; Cosens 2002; Goodman 2005). The Arizona I (1963) decision deemed this method the only 'feasible and fair way' to quantify water rights (Rusinek 1990).

In Arizona I (1963), the courts used PIA to determine that just less than 1 million acre-feet of water was reserved for the five Native American tribes involved in the case. This was a substantial amount of water, considering that the annual flow of the Colorado River was 14 million acre-feet (Arizona 1963; Cosens 2002). The only litigated quantification of waters of an entire stream system using this method after Arizona I (1963) was Wyoming v. United States (1989). Other quantifications using PIA were the result of settlement agreements (Cosens 2002).

The use of PIA for determining the quantity of water for Native Americans has received criticism. The main complaint from non-Natives is that PIA grants 'a very substantial amount of water' (Getches 1997). Native Americans are faced with difficult procedures for claims to their water. In addition, PIA relies on the conclusion that reservations were set-aside for agricultural purposes. However, agriculture was not always feasible. Recognizing this discrepancy, the Arizona Supreme Court developed an alternative method for quantification of Native American water rights.

\section{Arizona homeland method}

The Arizona Supreme Court determined in 2001 that the agricultural purpose for reservations was a flawed determination. Instead, the court concluded that reservations were created as a permanent homeland for Native Americans (Arizona Water Settlements Act 2004). Therefore, PIA was deemed invalid and a new method was developed.

One of the main issues of PIA is the inequity of water rights among tribes in different regions. Cosens (2002) states, 'Whereas southern tribes located in alluvial valleys near a large surface water source are entitled under an agricultural purpose quantified by the PIA method to ample water, tribes in more northern climes or mountainous terrain are left with insufficient rights to meet basic drinking water needs' (Cosens 2002). The Arizona homeland determination rectifies this inequity.

When Arizona adopted the homeland method for Native American reservations, the focus was taken away from a purpose- driven quantification. The court argued that reliance on historical documents for determining the purpose was inadequate because conflicting information was presented (Cosens 2002). Instead, Arizona utilized historical documents to determine the measure of need and right instead of purpose.

The most significant result of the homeland method was the acknowledgment of the need for development on Native American reservations. The homeland purpose adapted the measure of needs to those of individual tribes, based on their wants, development plans, cultural backgrounds, and geographic locations. This method determined the quantity of water needed and wanted, thus increasing beneficial use of resources.

\section{Current status of water rights in the US}

Negotiations have achieved a greater presence in water rights disputes, as negotiation to achieve mutual agreement in resolving potential disputes is preferable to litigation. Generally, litigation results in no benefit to the involved parties. The excessive financial costs limit the realization of any long-term economic planning and development (DOI 2008). Those involved understand that for everyone to benefit some give-and-take is required. Thus, negotiations have gained greater importance. 
The National Congress of American Indians (NCAI 2008) highlighted the government-togovernment connection between the Native Americans and the US. The transition of leadership in the 2008 Presidential election prompted the need to address the necessary changes to the Native American water rights policy. Historically, the government's water policy did little to reflect the considerations of tribal interests (NCAI 2008). The current use of negotiations has led to more regional development of water infrastructure (NCAI 2008).

Negotiations are models for how states, tribes, cities, farmers, and the federal government can work together effectively, thus generating benefits for all parties. The US Department of Interior is the lead for the federal government in negotiations (USBR 2009). The BIA is tasked with protecting, supporting, and representing Native Americans. The Bureau of Reclamation (USBR), which led the construction of large water projects, is the largest wholesaler of water in the US. Further, the USBR provides support for assessment of rights, negotiations, and the implementation of water development projects (USBR 2009). The role of the US is significant in water rights, especially implementation of development projects.

There is no ideal way to develop water resources (FAO 2001). Geography, funding, political support, and community support influence development projects. Funding is the biggest obstacle to overcome in Native American water projects. Funding comes from several sources. In 2009, the USBR had requests for \$150 million for Native American water projects (USBR 2008). The American Recovery and Reinvestment Act of 2009 has budgeted $\$ 90$ million for Native American water projects (USEPA 2009). Similar programs also provide funding to ensure beneficial use of resources. Adequate funding allows the realization of water rights for Native Americans.

\section{DISCUSSION}

There is no specific evidence that clearly answers the research questions about whether decisions concerning Native American water rights reflect the traditions and beliefs of the Native American population. The historically minimal involvement of Native Americans in establishing resource allocation policy offers one possible conclusion to those questions. Each case presents information to suggest the beliefs of Native Americans are not reflected in water rights legislation.

In Winters v. United States (1908), Rasch's argument was based on his interpretation of the beliefs of the Gros Ventre and Assiniboine tribes. However, no evidence exists to support his arguments or to show the tribes provided information. There is no evidence of the beliefs of these tribes either. Further, the motivations of the Superintendent are not fully known or understood for this case. The US was obliged to ensure the survival of the reservation. However, westward expansion and the creation of successful homesteads was one motivation for the development of treaties. Failure on either part would result in failure of the settlement of the western US. Therefore, taking the case to court potentially addressed several issues.

First, the action showed the tribes the US would act on their behalf. Thus, trust was gained. Second, tribal water enabled the continued pursuit of 'civilizing' tribes and made the land more productive, thus showing homesteaders the value of the area. Third, a decreased risk of disputes with the tribes existed if water was provided. All of these motivations, however, did not represent the interests of the tribes. Instead, emphasis was placed on the benefits to the US and settlers.

The McCarran Amendment (1952) did not represent any action for or against the Native Americans. It was established to improve the efficiency of the allocation process, and inclusion of Native American waters was essential to meet this goal. The subsequent adjudications are the main focus of its impacts. General adjudications include all parties. Conflict exists because the US must represent the interests of both the Native Americans and US water projects. It is difficult to conclude that Native Americans would receive the 
same level of representation as US agencies in cases involving federal funding of US water projects. The Amendment increases this potential conflict and inequity.

The Arizona v. California $(1963,1979,1983,2000,2006)$ cases are more difficult to consider. Arizona I (1963) introduced and adopted PIA for quantifying Native American reserved rights. However, PIA did not consider the wants or needs of tribes. Instead, the wants of the US formed the basis of the purpose of reservations. The inequities that resulted from PIA left some tribes without enough water for basic needs. These inequities are counter to the Native American belief that their relationship to the natural environment is sacred, with water as the blood of the tribes.

On the other hand, several aspects of the cases display consideration of the beliefs of Native Americans. In Winters v. United States (1908), Judge Hunt's conclusion was based on his interpretation that tribes would not have ceded lands without believing that water was still available. The Arizona homestead method was developed as a result of the inequities associated with PIA. The homestead method utilizes the input of tribes to establish a quantity of water based on the needs, wants, geography, cultural, and traditional beliefs of tribes.

Finally, the current negotiations bring all parties into the decision. Native Americans are directly involved in the negotiation process. The key distinction in these cases is that Native Americans make decisions based on their beliefs, instead of relying on the US to represent them. The beliefs of Native Americans are present in negotiations which are based on principles of cooperation and collaboration. A give-and-take relationship exists that Native Americans have utilized for centuries.

\section{CONCLUSIONS}

There are two possible conclusions:

1. It is feasible to conclude that Native Americans have not historically received the amount of support or attention required to understand their beliefs and incorporate them in decisions that directly affect them.

2. However, there is a growing pattern of inclusion of Native Americans and their beliefs in water rights determinations.

Therefore, it is concluded that, while not always present, Native Americans do have a voice in water rights in the US. Their influence has grown as awareness of the inequities of past legislation develops. The beliefs of Native Americans will become more prevalent and better understood as awareness grows.

\section{RECOMMENDATIONS}

It is difficult to recommend specific changes to apply to the legal process. However, some practices could benefit from modifications. The use of negotiations should continue. Faster and cost-effective decisions on water allocations are achieved, and the needs and wants of all parties are considered. Further development of the negotiation process can provide templates for other issues related to diverse populations in the US.

In addition, educational support for Native Americans in the legal profession should increase. The presence of Native Americans in the legal profession will enable better representation of their values and beliefs. Further, increased communication should emerge between Native Americans and non-Natives. There is an abundance of valuable information to gain from both sides. Native Americans should use the current environmental focus to promote their traditions, which allows for greater understanding and mutual respect between the two sides. Cooperation and collaboration are vital if Native American traditions are to continue and become reflected in US environmental policies. 


\section{REFERENCES}

AIJ 1978 A dwindling water supply and the Indian struggle to retain aboriginal and winters water rights. American Indian J. 4, 35-44.

Anderson, M. \& Moratto, M. 1996 Native American land-use practices and ecological impacts. Sierra Nevada Ecosystem Project: Final Report to Congress, University of California Davis, CA, USA, 2, pp. 187-206.

Arizona v. California. 1963373 U.S. 546, 83 S.Ct. 1468, 10 L. Ed.2d. 542

Arizona v. California. 1979 439U.S. 419, 99 S.Ct. 995, 58L.Ed.2d 627

Arizona v. California. 1983460 U.S. 605, 103 S.Ct. 1382, 75 L. Ed.2d 318

Arizona v. California. 2000530 U.S. 392, 120 S.Ct. 2304, 147 L. Ed.2d 374

Arizona v. California. 2006547 U.S. 150

Arizona Water Settlements Act. 2004 Public Law 108-451.

Babcock, H. M. 2006 Reserved Indian water rights in riparian jurisdiction: water, water everywhere, perhaps some drops for us. Cornell Law Rev. 91, 1203-1260.

BCPA 1928 Boulder Canyon Project Act. Public No. 642-70th Congress. United States Government Printing Office, Washington DC, USA.

BIA 2014 Indian Entities Recognized and Eligible to Receive Services from the United States Bureau of Indian Affairs. Bureau of Indian Affairs, US Department of Interior, Federal Register, 79, No. 19, 4748.

Burness, H. S., Cummings, R. G., Gorman,W. D. \& Lansford, R. R. 1928 The 'New' Arizona v. California: practicably irrigable acreage and economic feasibility. Nat. Resour. J. 22, 517-523.

Canby Jr., W. C. 2004 American Indian Law in a Nutshell, 4th edn. Thomson West, St. Paul, MN, USA.

CBO 2006 How Federal Policies Affect the Allocation of Water. Congressional Budget Office, Congress of the United States.

Cornell, G. 1990 Native American perceptions on the environment. Northwest Indian Q. VII (2), 3-13.

Cosens, B. A. 2002 The measure of Indian water rights: the Arizona Homeland Standard, Gila River Adjudication. Nat. Resour. J. 42, 835-872.

Deason, J. P., Schad Theodore, M. \& Sherk, G.W. 2001 Water policy in the United States: a perspective. Water Policy 3, 175-192.

DOI 2002 Indian Entities Recognized and Eligible to Receive Services from the United States Bureau of Indian Affairs. Notice. Federal Register. 67, No. 134, Part IV. Department of Interior, Washington DC, USA, pp. 46328-46333.

DOI 2008 Landmark Indian Water Rights Settlement Fully Implemented. News Release. United States Department of Interior, Washington DC, USA.

FAO 2001 FAO Legislative Study 70 -Water Rights Administration - Experience, Issues and Guidelines. Food and Agriculture Organization of the United Nations, Rome, Italy.

Getches, D. H. 1997 Water Law in a Nutshell, 3rd edn. West Publishing Company, St. Paul, MN, USA.

Goodman, J. J. 2005 Arizona v. California III: Res Judicata, Collateral Estoppel, and Indian water rights. J. Nat. Resour. Environ. Law 19, 273-283.

Harris, S. \& Harper, B. 1997 A Native American exposure scenario. Risk Analysis 17 (6), 789-795. 
Hu, D. 2006 Water Rights: An International and Comparative Study. Water Law and Policy Series. IWA Publishing, London, pp. 19-33.

Hudley Jr., N. 1982 The 'Winters' decision and Indian water rights: a mystery revealed. Western Hist. Quart. 13 (1), 17-42.

IEN 2001 Water and Indigenous Peoples: Indigenous Environmental Network Statement on the Endorsement and Adoption of the Indigenous Declaration on Water. Indigenous Environmental Network, Bemidji, MN.

Kappler, C. (Ed.). n.d. Indian Affairs: Laws and Treaties. Government Printing Office, Washington DC, USA. http:// digital.library.okstate.edu/kappler/Vol2/treaties.

Kleppinger, W. M. 1977 Determination of Federal water rights pursuant to the McCarran Amendment: general adjudications in Wyoming. Land Water Law Rev. 12, 457-484.

Kline, B. 2000 First along the River: A Brief History of the U.S. Environmental Movement, 2nd edn. Rowman and Littlefield Publishers, Lanham, MD.

Lyons, O. n.d. Indigenous Native American Prophecy. Indigenous Environmental Network. http://www.ienearth.org/pmec.html.

McCarran Amendment 195243 U.S.C. Section 666.

NCAI 2008 Indian Water Rights Policy Statement for the 2008 Presidential Administration. Indian Nations and the 2008 Presidential Transition, National Congress of American Indians, Washington DC, USA, pp. 33-35.

Pacheco, T. H. 1988 How big is big? The scope of water rights suits under the McCarran Amendment. Ecology Law Quart. 15, 627-669.

Rusinek, W. 1990 A preview of coming attractions? Wyoming v. United States and the Reserved Rights Doctrine. Ecology Law Quart. 17, 355-412.

Stein, J. 1997 The McCarran Amendment and the administration of tribal reserved water rights. Water Resources Update. Universities Council on Water Resources, 107, 9-15.

Trelease, F. J. 1963 Arizona v. California: Allocation of water resources to people, states, and nation. Supreme Court Rev. 158-205.

USBR 2008 Annual Budget of the US Bureau of Reclamation. United States Bureau of Reclamation, Washington DC, USA

USBR 2009 NAAO Water Rights Settlement Program. United States Bureau of Reclamation, Washington DC, USA.

USCB 2011 Table S0201 - Selected Population Profile in the United States, 2011 American Community Survey 1-Year Estimates. American Community Survey, Washington DC, USA.

USCB 2014 Census Glossary. United States Census Bureau, Washington DC, USA.

USEPA 2009 Clean Water and Drinking Water State Revolving Funds: ARRA Implementation, United States Environmental Protection Agency, Washington DC, USA.

US DOC 2001 Profiles of General Demographic Characteristics: 2000 Census of Population and Housing. United States Department of Commerce, Washington DC, USA.

Walston, R. E. 2006 The reserved rights doctrine: case study involving black canyon of the Gunnison national park. J. Contemp. Water Res. Educ. Universities Council on Water Resources. 133, 29-33.

Williams, S. M. 1997 Overview of Indian water rights. Water Resour. Update 107, 6-8.

Winters v. United States. 1908207 U.S. 564, 28 S.Ct. 207, 52 L.Ed. 340 
Wunder, J. R. (ed.) 1996 Constitutionalism and Native Americans, 1903-1968 (Native Americans and the Law: Contemporary and Historical Perspectives on American Indian Rights, Freedoms, and Sovereignty). Garland Publishing, New York, USA.

Wyoming v. United States. 1989492 U.S. 406, 109 S.Ct. 2994, 106 L.Ed.2d. 342 